\title{
Assessment of Genetic Diversity in Triticum spp., Secale Cereale And Triticale Using Issr Markers And Sds-Page
}

Rehab, M. M., Elsharkawy; El-Shawaf, I. I. S.; Bekhit*, M. M. M.; Hoda A. S., El-Garhy, and Salem, T. M. S. Department of Genetics and Genetic engineering, Faculty of Agriculture, Moshtohor, Benha University, Egypt.

*Corresponding author: Makhlouf.bakhit@fagr.bu.edu.eg

Genetic diversity among some wild close relatives of wheat was estimated using inter simple sequence repeats (ISSR) and SDS-PAGE markers. Four Triticum, Secale cereale and Triticale genotypes including seven Triticum, Secale and Triticale accessions belonging to one diploid (Secale cereale), three tetraploid (Triticum durum (4x)) and two hexaploid (Triticale (6x)) in addition to one hexaploid wheat (Triticum aestivum) species sampled from different ecogeographical regions of Egypt; a durum wheat cultivars 'Baniswef 1 and 3 and Sohag 3', a local wheat cultivars growing in upper Egypt 'Giza 168', a bread wheat cultivar and two triticale strains beside one rye strain were evaluated. Genetic diversity among wheat accessions was estimated using 11 ISSR primers. Of the approximately 153 detected ISSR markers, 65 (42\%) were polymorphic with 4 bands per used primer pair. Cluster analysis of 7 accessions belonging to the four species by UPGMA cluster analysis based on Jaccard's similarity estimates for ISSR data divided all accessions into one major cluster and Secale cereale separated from the major cluster. two major sub-clusters reflecting almost their genome composition. The first one included wheat species having AB genomes ('Baniswef 1 and 3 and Sohag 3'), while second cluster included wheat species having ABD and ABR genomes. The genetic similarity coefficients ranged from 0.36 between Triticale 1 and rye accession and 0.84 between Triticale $1(6 x)$ and Triticale $2(6 x)$. Two Triticum durum species of were ranked as the second most related species (0.81). The results of SDS-PAGE revealed a total number of 145 bands with molecular weights (MW) ranging from about $17 \mathrm{kDa}$ to $158 \mathrm{kDa}$, which were not necessarily present in the 7 genotypes. Data revealed seven common bands (monomorphic), six unique bands while the remaining 90 band were polymorphic with $62 \%$ polymorphism. The unique Bands at the molecular weight 158 and $41 \mathrm{kd}$ were the distinguishable band of Baniswef 3. The unique Band at the molecular weight $64 \mathrm{kd}$ was the distinguishable band detected of Sohag 3. The unique Bands at the molecular weight 62 and $55 \mathrm{kd}$ were detected only in Rye. The unique Band at the molecular weight $17 \mathrm{kd}$ was detected only in Baniswef 1.

Key words: Inter simple sequence repeats (ISSR), genetic diversity, wheat, Triticum spp., Rye, Triticale, SDSPAGE.

\section{Introduction}

Bread wheat (Triticum aestivum L.) is the most widely grown plant in the world due to its physiological characteristics that adapt wheat cultivars for production in a wide range of ecogeographical conditions and the chemical and physical properties of the wheat gluten that contribute to the wide use of wheat grain for many different food products. It is the staple food for $35 \%$ of the world's population, and is becoming increasingly important in the developing world (CIMMYT 2018). To meet the demand for developing high yielding and stressresistant wheat cultivars, it is desirable to increase the genetic base of this crop. There has been a growing concern about the remaining variability in the bread wheat gene pool which is grossly insufficient to address current and future breeding objectives (Rejesus et al., 1996). In last decades, the narrow genetic basis of modern wheat cultivars is well evident, as breeders prefer using either improved cultivars as parents or advanced breeding materials to accelerate the development of new cultivars. While in the beginning, selection was utilized to isolate pure lines from heterogeneous landraces or natural populations, today improved cultivars were used as parents in wheat breeding programs. It is therefore necessary to broaden the genetic base of wheat. The wild relatives of bread wheat, T. aestivum L., are considered as potential sources of useful alleles for bread- wheat improvement. The genus Secale L. and Triticum L. have contributed two of the three (A, B and $\mathrm{D}$ and $\mathrm{R}$ ) and one of the three (A, B and R) Triticale genomes, respectively. The genus Triticum contains many species comprising diploids, Tetraploid and hexaploids, that originated from center of origin (van Slageren, 1994). Consequently, study of the genetic diversity of the genetic resources of such species may provide significant information regarding their potential for breeding purposes. Genetic erosion caused by modern cultivation procedure has narrowed the genetic base of many crops, including bread wheat. Wild relatives and related species can be successfully crossed with bread wheat (Jiang et al., 1993; Sharma, 1995; Arzani et al., 2000). Consequently, genes from the wild relatives can be introgressed in the cultivated wheats through recombination of the homologous chromosomes, and undesirable gene linkages can be mostly broken by repeated backcrossing to cultivated 
wheat (Friebe et al., 1996). Amphiploids from interspecific crosses between tetraploid wheats and Aegilops species, as their close relatives, are useful bridging germplasm for introduction of desirable alien characters to bread wheats (Friebe et al., 1996). Egypt is very rich in habitat diversity due to the diversity in its geomorphology, topography and climate. This has aided the survival of a diverse plant species in the wild. Amongst the Egyptian flora, there are some of the most important food crops such as wheat and its wild close relatives. These species represent a large reservoir of useful characteristics that can be exploited for wheat improvement. Many agronomically interesting characterisics, comprising resistance to biotic and abiotic stresses have been transferred from these species to wheat (Jiang et al., 1993; Friebe et al., 1996). Comparative study of microsatellite diversity in wheat germplasm among a wide range of world areas indicated that the greatest genetic diversity originated from Iran (Huang et al., 2002). Traditionally, germplasm has been characterized based on agronomic and morphological studies, but recently use of molecular markers to study diversity of crop species has become common. DNA markers have the advantage of directly detecting sequence variation among cultivars. The use of Inter simple sequence repeats, ISSRs and is routine method for quickly and efficiently estimating relationships between lines and populations of many plant species. ISSR is an efficient, reproducible technique (Vos et al., 1995 and Sofallan et al., 2009).

ISSR has been widely used to discriminate between different accessions of a number of plants species including T. aestivum L. (Barrett and Kidwell 1998; Barrett et al., 1998; Bohn and Melchinger, 1999; Ridout and Donini,1999; Soleimani et al., 2002; Almanza Pinzon et al.,2003).

Quantification of genetic diversity in cultivated and wild crops has important implications for breeding programs and for the conservation of genetic resources. The primary objective of this study was to understand the extent and pattern of genetic diversity among diploid and polyploid wild species of wheat using ISSR marker.

\section{Materials and Methods}

\section{Plant materials}

A collection of seven Triticum, Rye and Triticale accessions belonging to one diploid Rye (Secale cereale), three belonging to $T$. durum, one belonging to Triticum aestivum and two belonging to Triticale were also used in this study, Table (1).

\section{Sodium dodecyl sulfate (SDS) - Polyacrylamide gel electrophoresis analysis}

The extraction of proteins was carried out in accordance with Galli and Feldman (1983). The relative mobilities of the subunits were obtained by SDS-PAGE according to Laemmli (1970). Low molecular weight standard proteins $(97.000,66.000$, $43.000,30.000$ and 20.100) were used. Gels with 10 per cent acrylamide, were stained in mixture of methanol: acetic acid: water (5:1:5) containing $0.2 \%$ of Comassie Brilliant Blue R250 (Sigma), and destained in methanol: acetic acid: water (5:1:5). HMW glutenins were designated according to Payne and Lawrence (1983) and LMW glutenins according to Nieto-Taladriz et al. (1997).

\section{ISSR analysis}

The experiment was conducted in the Biotechnology Laboratory, Department of Genetics and genetic engineering, Faculty of Agriculture, Benha University. Seven wheat and close relatives' accessions were used in this study (Table 1). Coding numbers are used according to the order of collection.

Table 1. Wild wheat relatives (Triticum and Secale accessions), synthetic wheat lines, durum and bread wheat cultivars used for diversity study.

\begin{tabular}{lllll}
\hline S/n & Species & Accessions & Genome & Growing status \\
\hline 1 & Secale cereale & Petikus & R & Experimental \\
2 & Triticum durum & Baniswef 1 & AB & commercial \\
3 & Triticum durum & Baniswef 3 & AB & commercial \\
4 & Triticum durum & Sohag 3 & AB & commercial \\
5 & Triticum aestivum & Giza 168 & ABD & commercial \\
6 & Triticale & Triticale 1 & ABR & Experimental \\
7 & Triticale & Triticale 3 & & Experimental \\
\hline
\end{tabular}

\section{Total Genomic DNA Extraction}

DNA was extracted from wheat young leaves (Saghai-Maroof et al., 1984). The extracted DNA was diluted to obtain a final concentration of $25 \mathrm{ng} / \mu \mathrm{L}$ in order to use it in the PCR amplification.

\section{PCR amplification}

The ISSR amplification was carried out in a $25 \mu \mathrm{L}$ volume, according to Hoisington et al., 1994. The amplifications were performed in a BioRad thermocycler. The PCR products were detected by $1.6 \%$ agarose gel electrophoresis that was stained with 
ethidium bromide. Then, the PCR products were visualized in a ultraviolet light using transluminator. In order to better distinguish the bands we used the molecular ladder contained known fragments.

\section{Data analysis}

The PCR product bands were scored as [1] for the presence and [0] for absence. The obtained data were used for analyses of genetic associations in the examined wheat material. A similarity matrix was constructed using the NTSYS-pc (Numerical Taxonomy and Multivariate Analysis for personal computers) software, version 2.1 (Rohlf, 2000). For all pairs, wise comparisons were done, according to Jaccard's similarity coefficient. A dendrogram was constructed from the similarity matrix using the UPGMA method (Unweighted Pair-Group Method with Arithmetical Averages) and the SAHN subprogram (Sequential, Agglomerative, and Hierarchical and Nested clustering).

Table 2. ISSR primers (and their sequences) which produced polymorphisms across three durum wheat cultivars, one bread wheat cultivar, two triticale cultivars and one rye cultivar, respectively.

\begin{tabular}{cc}
\hline Primer & Sequence \\
\hline ISSR- 1 & 5'-AGAGAGAGAGAGAGAGTC-3' \\
ISSR- 2 & 5'-AGAGAGAGAGAGAGAGTG-3' \\
ISSR- 4 & 5'-ACACACACACACACACTG-3' \\
ISSR- 5 & 5'-GTGTGTGTGTGTGTGTAG-3' \\
ISSR- 11 & 5'-ACACACACACACACACTA-3' \\
ISSR- 12 & 5'-ACACACACACACACACTC-3' \\
ISSR- 13 & 5'-AGAGAGAGAGAGAGAGTT-3' \\
ISSR- 14 & 5'-CTCCTCCTCCTCCTCTT-3' \\
ISSR- 15 & 5'-CTCTCTCTCTCTCTCTRG-3' \\
ISSR- 18 & 5'-GAGCACACACACACACAT-3' \\
ISSR- 20 & 5'-GAGTGTGTGTGTGTGTGT-3' \\
\hline
\end{tabular}

Molecular fingerprints based on SDS- proteins:

SDS-PAGE: Data presente1d in Fig. 1 and Table 2 summarized the SDS-PAGE of soluble proteins for the seven accessions of wheat. Analysis of gel revealed that molecular weight of protein subunits ranged between 11.99 to $72.00 \mathrm{kDa}$.

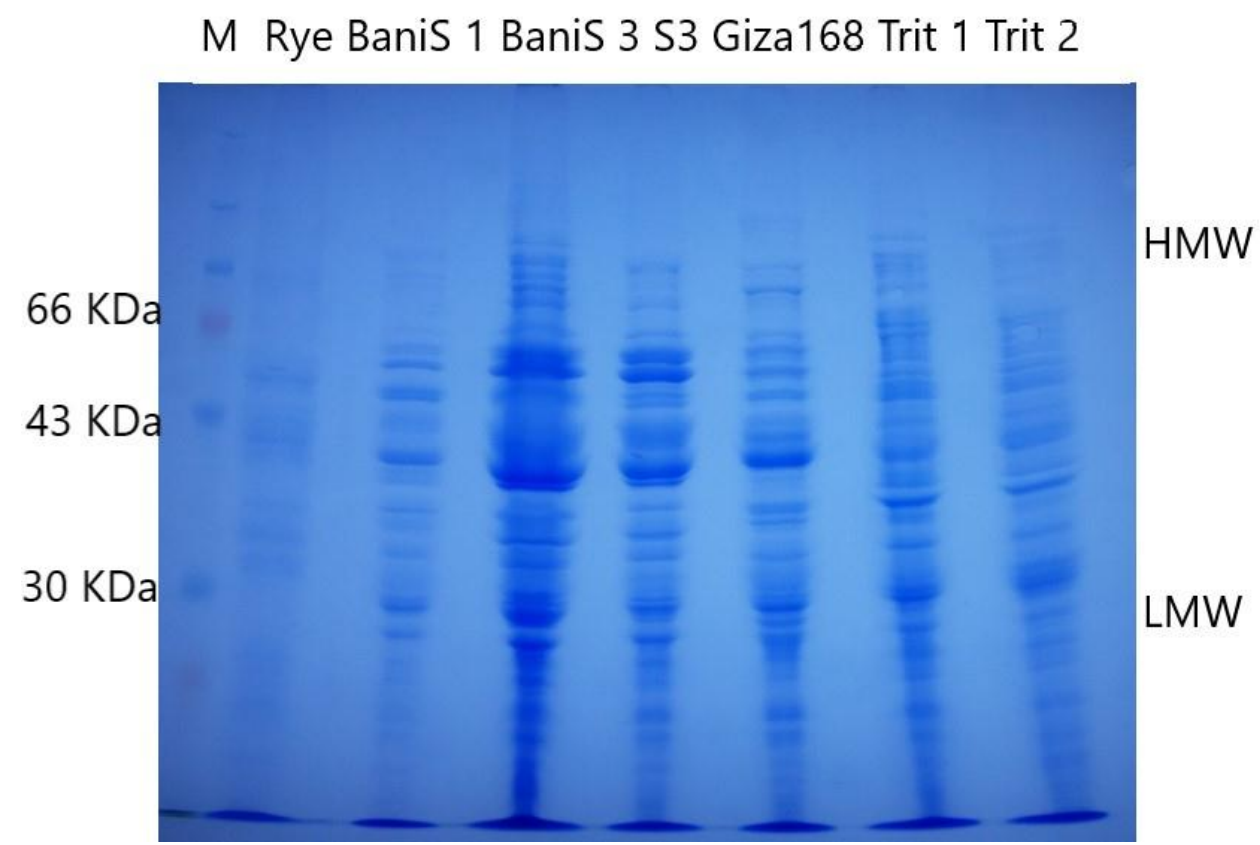

Fig. (1): SDS-PAGE profiles of soluble proteins extracted from seven genotypes of wheat and close relatives. 


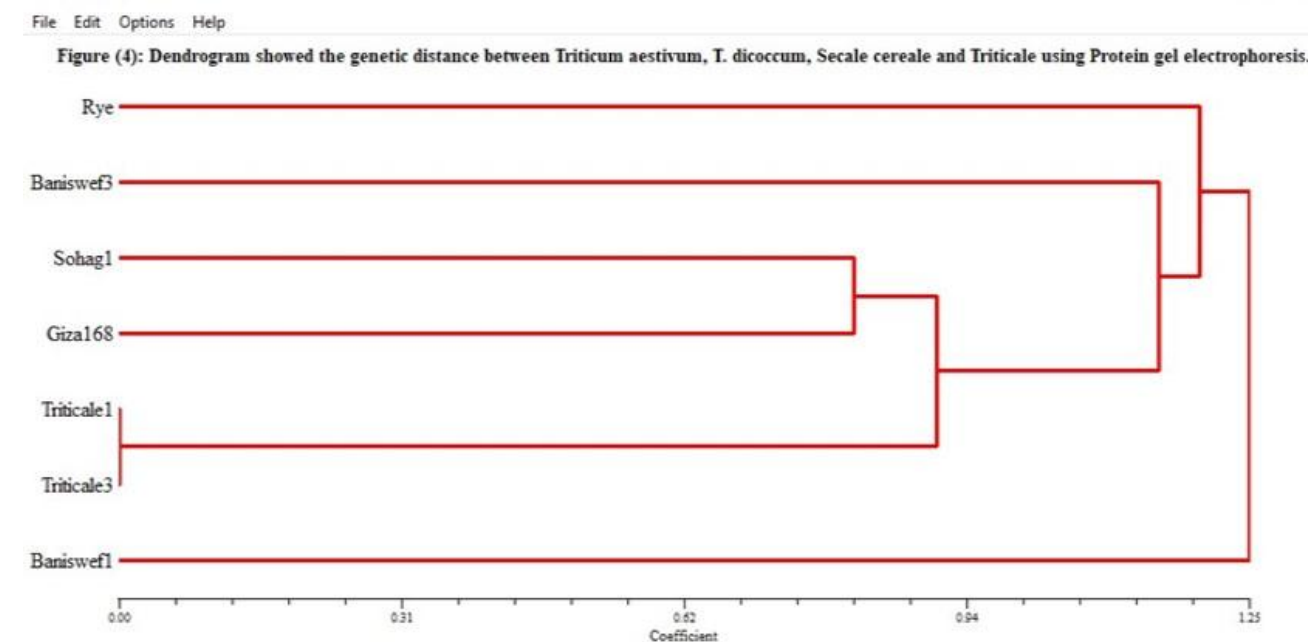

Fig. 2. Dendrogram based on UPGMA of Jaccard's similarity matrix represents the genetic relatedness among $T$ aestivum, T. dicoccum, Secale cereale and Triticale cultivars based on the analysis of Protein electrophoresis banding patterns.

Table 3. Revealed the molecular weights of the soluble proteins extracted from seven genotypes of wheat and close relatives.

\begin{tabular}{|c|c|c|c|c|c|c|c|c|}
\hline M W. & Rye & B 1 & B 3 & S 3 & G 168 & T 1 & T 2 & \\
\hline 158 & 0 & 0 & 1 & 0 & 0 & 0 & 0 & Unique band \\
\hline 137 & $\mathbf{0}$ & 1 & $\mathbf{0}$ & $\mathbf{0}$ & 1 & 1 & 1 & Polymorphic bands \\
\hline 129 & $\mathbf{0}$ & $\mathbf{0}$ & 1 & $\mathbf{0}$ & 1 & $\mathbf{0}$ & $\mathbf{0}$ & Polymorphic bands \\
\hline 126 & $\mathbf{0}$ & $\mathbf{0}$ & 1 & $\mathbf{0}$ & $\mathbf{0}$ & 1 & 1 & Polymorphic bands \\
\hline 124 & $\mathbf{0}$ & $\mathbf{0}$ & 1 & $\mathbf{0}$ & $\mathbf{0}$ & 1 & 1 & Polymorphic bands \\
\hline 116 & $\mathbf{0}$ & $\mathbf{0}$ & $\mathbf{0}$ & $\mathbf{0}$ & $\mathbf{0}$ & 1 & 1 & Polymorphic bands \\
\hline 114 & $\mathbf{0}$ & 1 & 1 & $\mathbf{0}$ & $\mathbf{0}$ & $\mathbf{0}$ & $\mathbf{0}$ & Polymorphic bands \\
\hline 110 & $\mathbf{0}$ & $\mathbf{0}$ & $\mathbf{0}$ & 1 & 1 & 1 & 1 & Polymorphic bands \\
\hline 107 & 1 & 1 & 1 & $\mathbf{0}$ & $\mathbf{0}$ & $\mathbf{0}$ & $\mathbf{0}$ & Polymorphic bands \\
\hline 102 & 1 & 1 & 1 & 1 & 1 & 1 & 1 & Common bands \\
\hline 98 & $\mathbf{0}$ & 1 & 1 & 1 & 1 & $\mathbf{0}$ & $\mathbf{0}$ & Polymorphic bands \\
\hline 94 & $\mathbf{0}$ & $\mathbf{0}$ & $\mathbf{0}$ & $\mathbf{0}$ & $\mathbf{0}$ & 1 & 1 & Polymorphic bands \\
\hline 86 & $\mathbf{0}$ & 1 & 1 & 1 & 1 & 1 & 1 & Polymorphic bands \\
\hline 79 & $\mathbf{0}$ & 1 & 1 & 1 & 1 & 1 & 1 & Polymorphic bands \\
\hline 74 & 1 & 1 & 1 & 1 & 1 & 1 & 1 & Common bands \\
\hline 70 & 1 & $\mathbf{0}$ & $\mathbf{0}$ & $\mathbf{0}$ & $\mathbf{0}$ & 1 & 1 & Polymorphic bands \\
\hline 67 & $\mathbf{0}$ & 1 & 1 & 1 & 1 & 1 & 1 & Polymorphic bands \\
\hline 64 & $\mathbf{0}$ & $\mathbf{0}$ & $\mathbf{0}$ & 1 & 0 & $\mathbf{0}$ & $\mathbf{0}$ & Unique band \\
\hline 62 & 1 & $\mathbf{0}$ & $\mathbf{0}$ & $\mathbf{0}$ & $\mathbf{0}$ & $\mathbf{0}$ & $\mathbf{0}$ & Unique band \\
\hline 58 & 1 & 1 & 1 & 1 & 1 & 1 & 1 & Common bands \\
\hline 55 & 1 & $\mathbf{0}$ & $\mathbf{0}$ & $\mathbf{0}$ & $\mathbf{0}$ & $\mathbf{0}$ & $\mathbf{0}$ & Unique band \\
\hline 52 & 1 & 1 & 1 & 1 & 1 & 1 & 1 & Common bands \\
\hline 49 & 1 & 1 & 1 & 1 & 1 & $\mathbf{0}$ & $\mathbf{0}$ & Polymorphic bands \\
\hline 46 & $\mathbf{0}$ & 1 & 1 & 1 & 1 & 1 & 1 & Polymorphic bands \\
\hline 42 & 1 & 1 & 1 & 1 & 1 & 1 & 1 & Common bands \\
\hline 41 & $\mathbf{0}$ & $\mathbf{0}$ & 1 & $\mathbf{0}$ & $\mathbf{0}$ & $\mathbf{0}$ & $\mathbf{0}$ & Unique band \\
\hline 39 & $\mathbf{0}$ & $\mathbf{0}$ & $\mathbf{0}$ & $\mathbf{0}$ & 1 & 1 & $\mathbf{0}$ & Polymorphic bands \\
\hline 37 & 1 & 1 & 1 & 1 & 1 & 1 & 1 & Common bands \\
\hline 34 & 1 & 1 & 1 & 1 & 1 & 1 & 1 & Common bands \\
\hline 32 & 1 & $\mathbf{0}$ & $\mathbf{0}$ & 1 & 1 & $\mathbf{0}$ & $\mathbf{0}$ & Polymorphic bands \\
\hline 30 & $\mathbf{0}$ & 1 & 1 & 1 & 1 & 1 & 1 & Polymorphic bands \\
\hline 28 & $\mathbf{0}$ & 1 & 1 & 1 & 1 & 1 & $\mathbf{0}$ & Polymorphic bands \\
\hline 25 & $\mathbf{0}$ & 1 & 1 & 1 & 1 & 1 & 1 & Polymorphic bands \\
\hline 21 & 0 & 1 & $\mathbf{0}$ & $\mathbf{0}$ & $\mathbf{0}$ & 1 & 1 & Polymorphic bands \\
\hline 19 & $\mathbf{0}$ & $\mathbf{0}$ & $\mathbf{0}$ & 1 & 1 & 1 & 1 & Polymorphic bands \\
\hline 17 & 0 & 1 & 0 & 0 & 0 & 0 & 0 & Unique band \\
\hline Total & 13 & 21 & 23 & 20 & 22 & 24 & 22 & 145 \\
\hline
\end{tabular}


Table 4. Nei's genetic identity between Wheat species, Secale cereale and Triticale for SDS-PAGE patterns of soluble proteins extracted from seven accessions.

\begin{tabular}{llllllll}
\hline & Rye & Banyswef 1 & Banyswef 3 & Sohag 1 & Giza 168 & Triticale1 & Triticale2 \\
\hline Rye & 1.00 & & & & & & \\
Baniswef 1 & 0.38 & 1.00 & & & & & \\
Baniswef 3 & 0.38 & 0.57 & 1.00 & & & & \\
Sohag 1 & 0.50 & 0.52 & 0.61 & 1.00 & & & \\
Giza 168 & 0.47 & 0.50 & 0.50 & 0.81 & 1.00 & & \\
Triticale1 & 0.41 & 0.52 & 0.61 & 0.75 & 0.61 & 1.00 & 1.00 \\
Triticale2 & 0.41 & 0.52 & 0.61 & 0.75 & 0.61 & 1.00 & \\
\hline
\end{tabular}

Thirteen bands were obtained in rye. Twenty-one bands were detected in Baniswef. Twenty third bands were found in Baniswef 3. Sohag 1 revealed twenty bands. Giza 168 and Triticale 2 showed 22 bands. The highest number of bands (24) was observed in Triticale 1. Gliadin and glutenin, two storage protein groups, have been recognized in the endosperm (Wall, 1979 and Rodriguez-Quijano et al.,(2010). Gliadin and glutenin are synthesized on the endoplasmic reteculum in the developing endosperm. Both of them are deposited in the developing endosperm. Both of them are deposited in protein bodies (Shewry and Niflin, 1985). Glutenins are considered as the major determinants of elesticity (Tatham et. Al., 1985). The analysis revealed that higher variability between the electrophoretic bands in the 7 wheat accessions. The study showed an electrophoretic variability of the proteins in the three original tetraploid parents; Baniswaf 1 and 3 in addition to Sohag 3 and one hexaploid bread wheat variety. Geat variation between Petkus and the hexaploid triticale 1 and 2. Data resulted from this study can be useful for the breeding of wheat including one or more rye chromosomes. Moreover, it is very important to predict the quality of the resulted proteins in breeding programes
(Mahgoub, 1988; Bakheet, 1990 and Demais et al., 2018).

\section{Results}

All 11 primers generated 153 bands of different sizes for 7 accessions of the genus Wheat and its close relatives with an average of 14 bands per primer, (Table 2). ISSR pattern obtained with the eleven primers are shown in Fig. 4. Maximum number of fragments ( 25 bands) was found with primer ISSR 15, whereas the smallest number ( 8 bands) was generated by primer ISSR 11 . The sum of 65 out of 153 fragments was polymorphic, with $42.84 \%$ of mean percentage of polymorphic bands (PPB). The number of polymorphic bands varied from 13 (for primer ISSR 15) to 1 (for primer ISSR 18). The potential of ISSR markers to generate genetic information through polymorphic fragments depends on the microsatellite frequency and their distribution in the genome wide scale of the species (Morgante et al., 1993, Bekhit 2007a and b and Bekhit et al., 2007c). In agreement of this result, in the study of microsatellite primers in wheat it was assumed that the polymorphism rate would be higher when the motifs are composed of three or four nucleotides (Song et al., 2002).

Table 5. List of ISSR primers including nucleotide sequences, number of monomorphic and polymorphic bands, total bands and percentages of polymorphism for ISSR primers among seven accessions of wheat species, rye and triticales.

\begin{tabular}{|c|c|c|c|c|c|c|c|}
\hline No. & $\begin{array}{c}I S S R \\
\text { primers }\end{array}$ & $\begin{array}{r}\text { Total } \\
\text { bands }\end{array}$ & $\begin{array}{l}\text { No. of } \\
\text { polymorphic } \\
\text { bands }\end{array}$ & $\begin{array}{c}\% \text { of } \\
\text { polymorphism }\end{array}$ & $\begin{array}{c}\text { Monomorphic } \\
\text { bands }\end{array}$ & $\begin{array}{c}\text { Unique } \\
\text { bands }\end{array}$ & $\begin{array}{l}\text { Mean of } \\
\text { band } \\
\text { frequency }\end{array}$ \\
\hline 1 & ISSR- 1 & 14 & 9 & $86 \%$ & 2 & 3 & 0.6 \\
\hline 2 & ISSR- 2 & 13 & 4 & $77 \%$ & 3 & 6 & 0.5 \\
\hline 3 & ISSR- 4 & 12 & 5 & $83 \%$ & 2 & 5 & 0.5 \\
\hline 4 & ISSR- 5 & 12 & 7 & $92 \%$ & 1 & 4 & 0.5 \\
\hline 5 & ISSR- 11 & 8 & 1 & $38 \%$ & 5 & 2 & 0.7 \\
\hline 6 & ISSR- 12 & 11 & 1 & $36 \%$ & 7 & 3 & 0.7 \\
\hline 7 & ISSR- 13 & 18 & 11 & $94 \%$ & 1 & 6 & 0.4 \\
\hline 8 & ISSR- 14 & 17 & 9 & $82 \%$ & 3 & 5 & 0.5 \\
\hline 9 & ISSR- 15 & 25 & 13 & $84 \%$ & 4 & 8 & 0.5 \\
\hline 10 & ISSR- 18 & 10 & 1 & $20 \%$ & 8 & 1 & 0.9 \\
\hline \multirow[t]{2}{*}{11} & ISSR- 20 & 12 & 4 & $58 \%$ & 5 & 3 & 0.6 \\
\hline & Total & 153 & 65 & & 41 & 46 & \\
\hline
\end{tabular}


The highest number of ISSR fragments was obtained for Secale cereale (92), whereas the lowest (79) was for Triticum durum (Sohag 3). At the species level, the highest percentage of polymorphism loci $(92 \%)$ was observed in Triticale while the lowest $(54 \%)$ was observed in Rye (Table 3).

Table 6. Genetic distances, as the total number of ISSR band differences, among the studied Triticum aestivum, T. dicoccum, Secale cereale and Triticale genotypes after using twelve primers.

\begin{tabular}{cccccccc}
\hline & Rye & Banyswef 1 & Banyswef 3 & Sohag 1 & Giza 168 & Triticale1 & Triticale2 \\
\hline Rye & 1.00 & & & & & & \\
Banyswef 1 & 0.61 & 1.00 & & & & & \\
Banyswef 3 & 0.60 & 0.90 & 1.00 & & & & \\
Sohag 1 & 0.58 & 0.80 & 0.83 & 1.00 & & & \\
Giza 168 & 0.59 & 0.81 & 0.80 & 0.80 & 1.00 & & \\
Triticale1 & 0.54 & 0.75 & 0.75 & 0.75 & 0.83 & 1.00 & \\
Triticale2 & 0.55 & 0.78 & 0.75 & 0.74 & 0.87 & 0.92 & 1.00 \\
\hline
\end{tabular}

The cophenetic coefficient of ISSR clustering from Jaccard's similarity matrix was equal to 0.9968 $(\mathrm{p}=0.002)$. Therefore, to infer phylogenetic relationships, the $0 / 1$ matrix was subjected to the construction of similarity matrix using Jaccard's coefficients. The unweighted pair group method with arithmetic mean (UPGMA) dendrogram based on Jaccard's coefficients indicated that 7 accessions were divided into one major cluster with a separated rye. The major cluster was divided into two main clusters. The first major cluster was divided into 2 subclusters (A and B). The subcluster A was composed of three accessions of Triticum durum (Beniswaf 1 and Baniswef 3 in a subcluster and Sohag 3 separated in a subcluster). the subcluster B having 3 accessions of tritcum aestivum (Giza 168 separated in a subcluster) and Triticale (Triticale 1 and 2 in a subcluster), (Fig. 2). Similarity of T. durum and T. aestivum accessions was from 0.21 (between 3 and 3 accessions) to 0.12 (between accessions 1 and 2).

Our results confirmed that the ISSR markers had the potential to detect genetic variability in Tetraploid wheat, hexaploid wheat, Rye and triticale varieties (Fig. 1). According to these results, it was confirmed that the ISSR molecular markers could properly differentiate wheat varieties with genomes A, B and D from Genome $\mathrm{R}$ in rye and triticale and could be used in variety identification purposes.

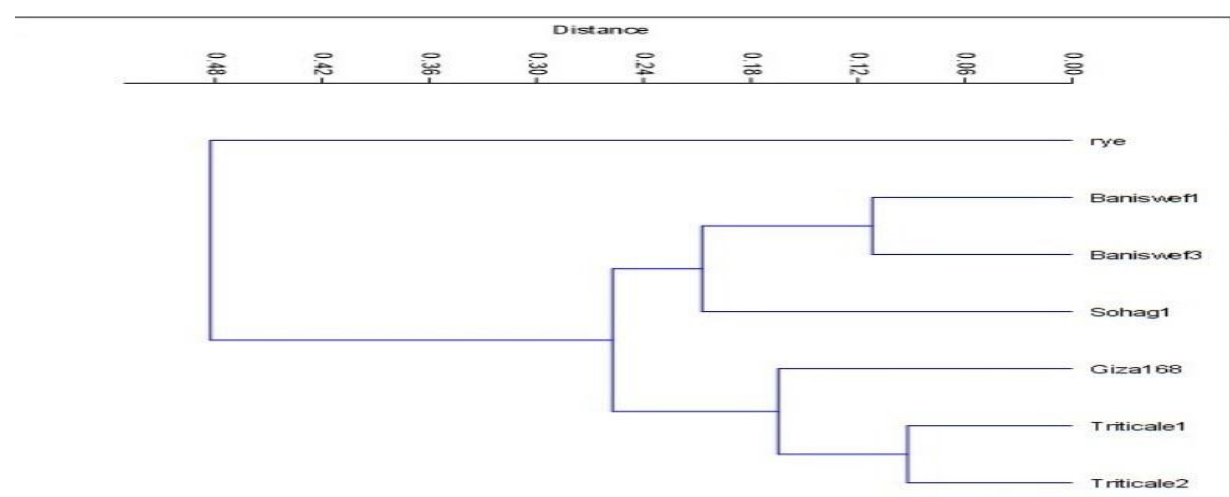

Fig. 2. Dendrogram of seven wheat species, rye and triticale based on Jaccard genetic similarity coefficients using 11 ISSR polymorphisms.

The molecular markers are commonly used in studies of population structure, genetic diversity for pre-breeding and breeding germplasms, and in distinguishing one individual genotype to preserve the property of breeding rights. ISSR technique has been proven to be useful in population genetic diversity studies (Lage et al., 2003; Arzani et al., 2005 and Reif et al., 2005 and Shoaib and Arabi (2006)).

In this study, we found a high degree of polymorphism in the Triticum accessions studied (with values in range of 20-94 and a mean of $42.48 \%$ ) (Table 2). These primers also were showed high polymorphism in other species. Therefore, these primers may be useful to investigate the genetic diversity of other members of poaceae or Gramineae family.

The UPGMA dendrogram based on Jaccard's coefficients indicated that 7 accessions were divided into two major clusters (Fig. 1). All species in first major cluster have tetraploid wheat with the two genomes, while the species of second cluster have hexaploid wheat and triticale with the three genomes.

\section{Conclusion}

In conclusion, ISSR is an effective and promising molecular marker system for detecting genetic variation in wheat species. Our data provide evidence 
of a genetic diversity between the tested wheat, rye and triticale spp. accessions. The results obtained in this study indicated the highest identity between Triticale 1 and Triticale 2 and the lowest identity between Triticum durum and Secale cereale.
Furthermore, the results showed an increased distance between the accession 1 and other accessions of Triticum species. Overall, this study demonstrated that the ISSR is a useful tool in Wheat genomic diversity studies and to detect their relationships.
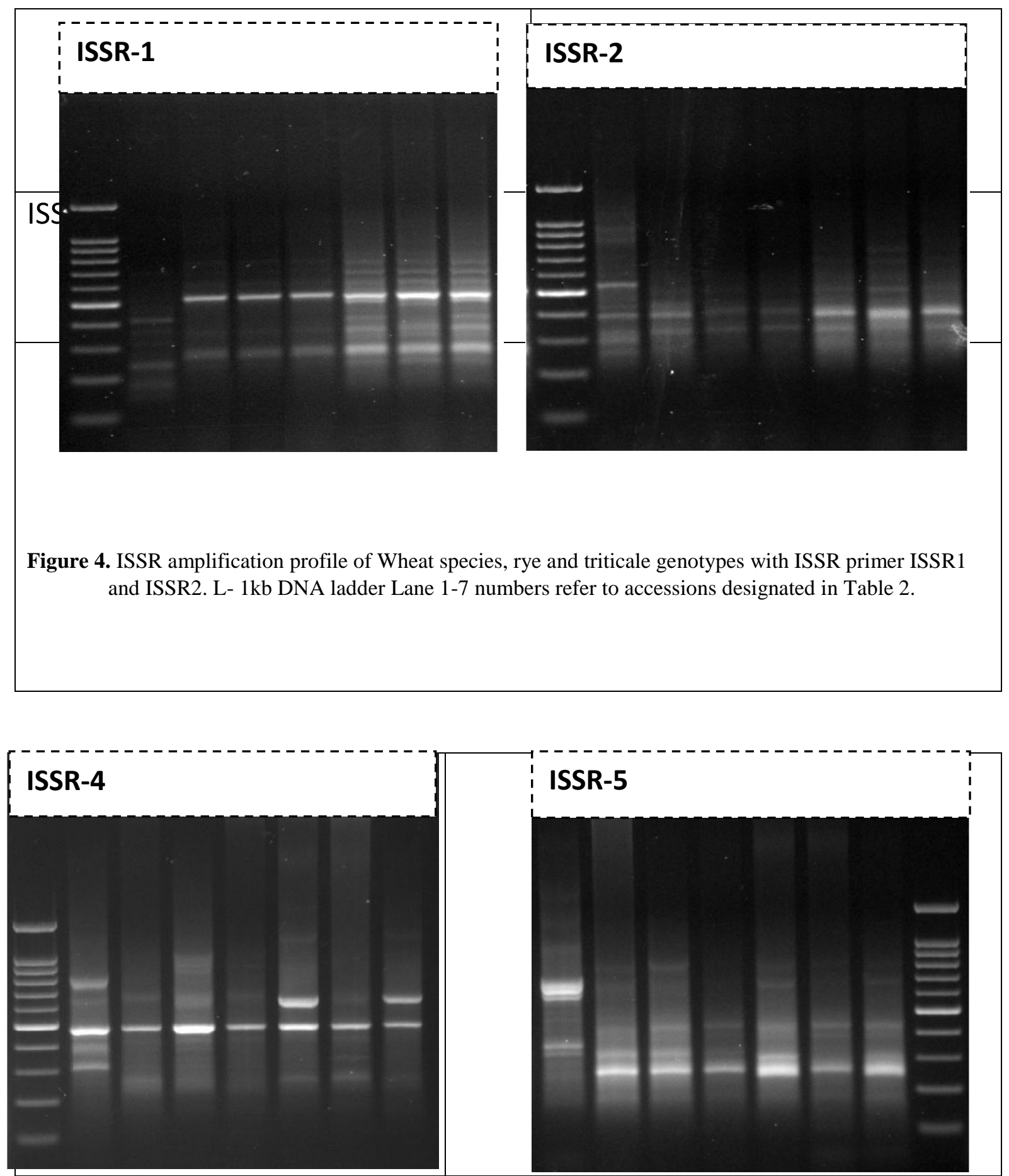

Cont Figure 4. ISSR amplification profile of Wheat species, rye and triticale genotypes with ISSR primer ISSR5 and ISSR6. L- 1kb DNA ladder Lane 1-7 numbers refer to accessions designated in Table 2. 

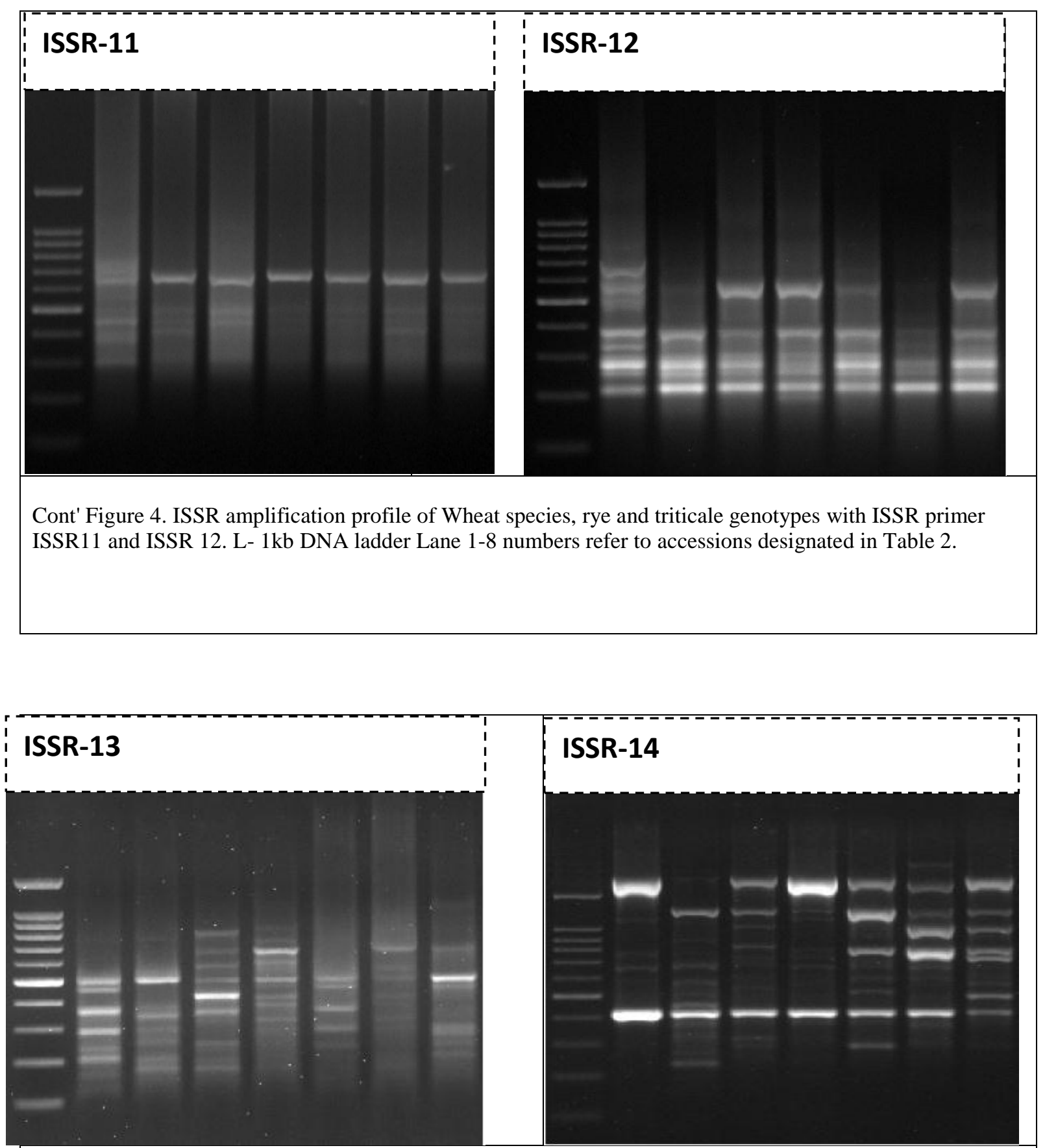

Cont Figure 4. ISSR amplification profile of Wheat species, rye and triticale genotypes with ISSR primer ISSR 13 and ISSR 14. L- 1kb DNA ladder Lane 1-7 numbers refer to accessions designated in Table 2. 

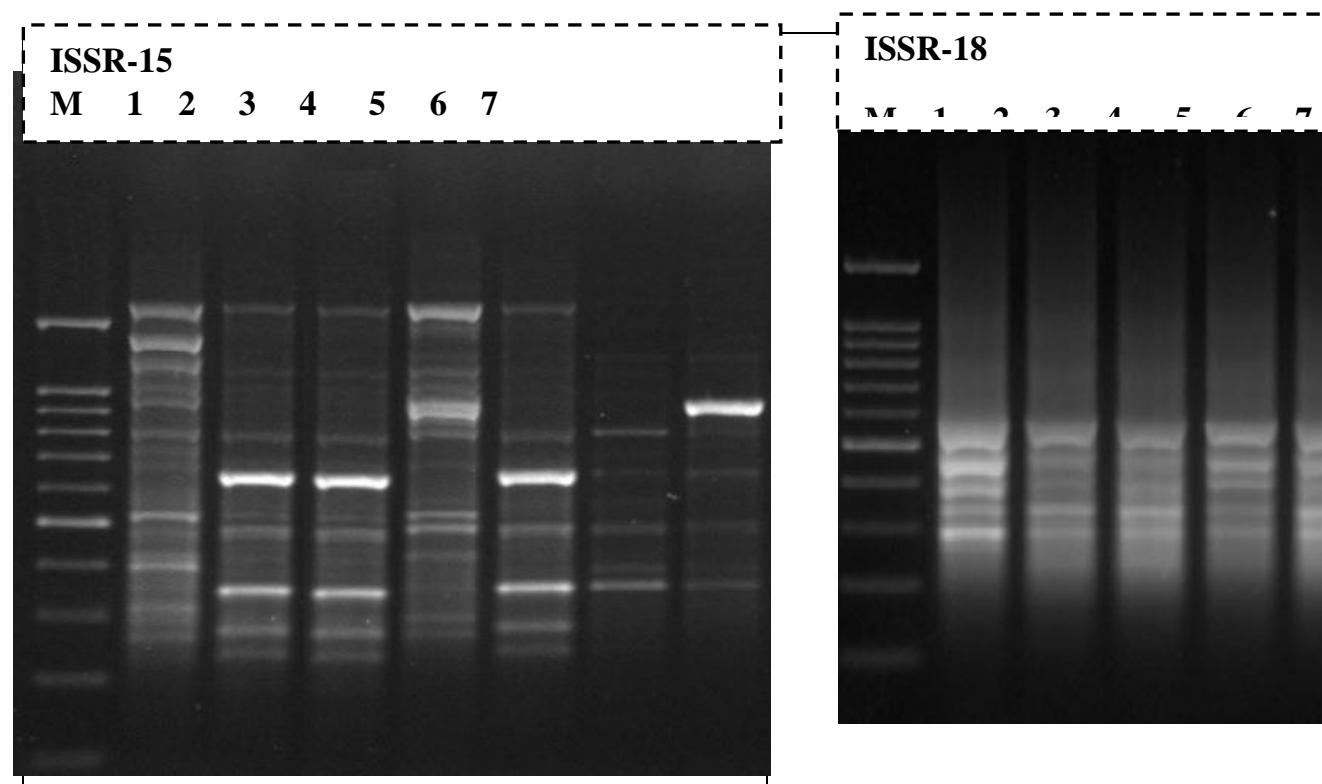

DNA ladder Lane 1-7 numbers refer to Wheat species, rye and triticale designated in Table 2.

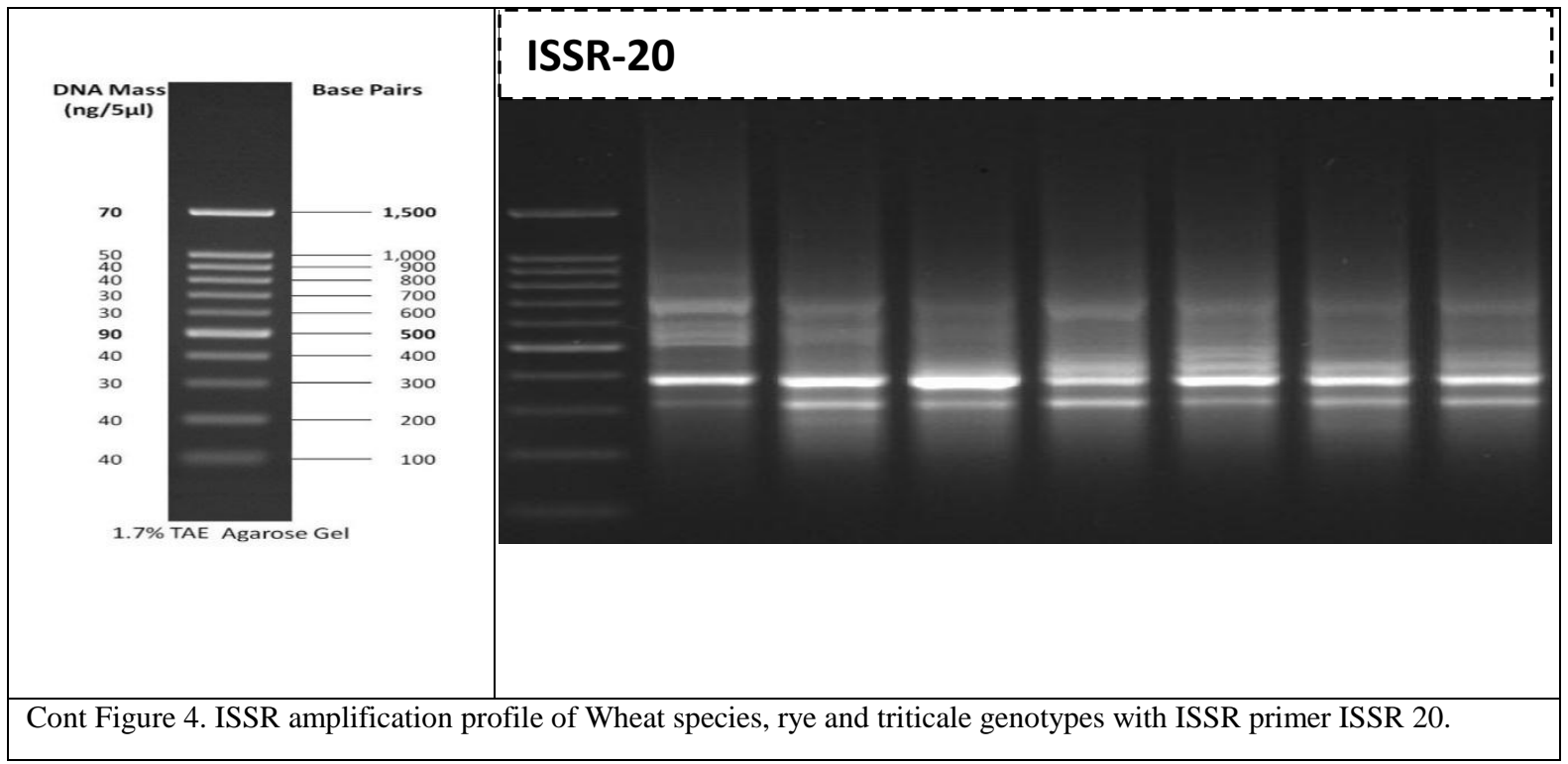

\section{References}

Almanza-Pinzon I, Khairallah M, Fox PN, Warburton ML (2003). Comparison of molecular markers and coefficients of parentage for the analysis of genetic diversity among spring bread wheat genotypes. Euphytica 130: 77-86.

Arzani A, Khalighi MR, Shiran B, Kharazian N (2005). Evaluation of diversity in wild relatives of wheat. Czech. J. Genet. Plant Breed. 41: 112-117.

Arzani A, Poursiahbidi M, Rezai A (2000). Influences of durum wheat and Aegilops genotypes on the production of amphihaploid plants. Iran Agric. Res. 19: 49-62.
Barrett BA, Kidwell KK (1998). AFLP-based genetic diversity assessment among wheat cultivars from the Pacific Northwest. Crop Sci. 38: 1261-1271.

Barrett BA, Kidwell KK, Fox PN (1998). Comparison of AFLP and pedigree-based genetic diversity assessment methods using wheat cultivars from the Pacific Northwest. Crop Sci. 38: 1271-1278.

Bekhit, M. M. M. (2007a): Molecular studies on wheat-rye chromosome translocation line (4BS.4BL-5RL) showing highly efficient copper absorption. Annals of Agric. Sci. Moshtohor, 45 (2):. 
Bekhit, M. M. M. (2007b): Grain surface scan and cytological studies in a selected wheat line possessing the 4BS.4BL-5RL translocation. Annals of Agric. Sci. Moshtohor, 45 (2):

Bekhit, M. M. M.; Sherif, H. S.; El-Hosary, A. A.; Moustafa, M. A. and El-Maghraby, M. A. (2007c): Genetic relationships among some bread wheat genotypes as revealed by SSR analysis. Egypt. J. Genet. Cytol., 36 (1): 67-31.

Bohn M, Utz HF, Melchinger AE (1999). Genetic similarities among winter wheat cultivars determined on the basis of RFLPs, AFLPs, SSRs and their use for predicting progeny variance. Crop Sci 39:228-237.

CIMMYT (2018). Wheat in the developing world. http://www.cimmyt.org /research/ wheat/map/ developing_world/ index.htm

Demais, Seham M,; Bekhit, M. M. M.; Abdel Sabour, M. S.; Salem, T. M. S. and Gad, K. I. (2018):Cytological and molecular studies in some interspecific hybrids resulted from crossing between tetraploid and hexaploid wheat. $4^{\text {th }}$ international conference on biotechnology applications in agriculture (ICBAA), Benha University, Moshtohor and Hurghada, 4-7 April, 2018, Egypt.

Doyle, J. J. and J. L. Doyle. (1987). A rapid DNA isolation procedure for small quantities of fresh leaf tissue. Phytochemical Bulletin 19: 11-15.

Friebe B, Jiang J, Raupp WJ, McIntosh RA, Gill BS (1996). Characterization of wheat alien translocations conferring resistance to diseases and pests. Euphytica 91: 59-87.

Galli G. and Feldman M. (1983) Genetic control of endosperm proteins in wheat 1 . The use of high resolution one dimensional gel electrophoresis for the allocation of genes coding for endosperm protein subunits in the common what cultivar Chinese Spring. Theor. Appl. Genet., 64, 97-101.

Hoisington, D., M. Khairallah and D. Gonzalea-deleon (1994). Laboratory protocols, CIMMYT Applied Molecular Genetics Laboratory. 2nd ed. (Available online at http,//www. Cimmyt.org/ abc/protocols/ manualabc .html verified 14 nov. 2004). Cimmyt, Mexico.

Huang XQ, Borner A, Roder M, Ganal MW (2002). Assessing genetic diversity of wheat (Triticum aestivum L.) germplasm using microsatellite markers. Theor. Appl. Genet. 105: 699-707.

Jiang J, Friebe B, Gill BS (1993). Recent advances in alien gene transfer in wheat. Euphytica 73: 199212.

Lage J, Warburton ML, Crossa J, Skovmand B, Andersen SB (2003). Assessment of genetic diversity in synthetic hexaploid wheats and their Triticum dicoccum and Aegilops tauschii parents using AFLPs and agronomic traits. Euphytica 134: 305-317.

Laemmli, U.K. (1970). Cleavage of structural proteins during the assembly of the head of bacteriophage $\mathrm{T}_{4}$. Nature 227: 680-685.

Nieto-Taladriz M.T., Ruiz M., Martinez M.C., Vazquez J.F. and Carrillo J.M. (1997) Variation and classification of B lowmolecular-weight glutenin subunits alleles in durum wheat.Theor. App. Genet., 95, 1155-1160.

Payne P.I. and Lawrence C.J. (1983) Catalogue of alleles for the complex gene loci Glu-A1, Glu-B1, and Glu-D1 witch code for high-molecular-weight subunits glutenin hexaploid wheat. Cereal Res. Commun. 11:29-35.

Reif JC, Zhang P, Dreisigacker S, Warburton ML, van Ginkel $M$, Hoisington $D$, Bohn $M$, Melchinger AE (2005). Wheat genetic diversity trends during domestication and breeding. Theor. Appl. Genet. 110: 859-864.

Rejesus RM, van Ginkel M, Smale M (1996). Wheat Breeder's Perspectives of Genetic Diversity and Germplasm Use. Wheat Special Report 40. Mexico D.F., CIMMYT.

Rodriguez-Quijano, M.; Lucas, R.; Ruiz, M.; Giraldo, P.; Espi, A. and and J.M. Carrillo (2010): Allelic Variation and Geographical Patterns of Prolamins in the USDA-ARS Khorasan Wheat Germplasm Collection. crop science. 50: 2383-239.

Rohlf, F. J. (2000). NTSYS pc numerical taxonomy and multivariate analysis system user guide. New York University, New York.

Saghai-maroof, M. A., K. Soliman, R. A. Jorgenson and R. W. Allard (1984). Ribosomal DNA spacer-length polymorphisms in barley, Mendelian inheritance, chromosomal location, and population dynamics. PNAS. 81:8014-8018.

Sharma HC (1995). How wide can a wide cross be? Euphytica 82: 43- 64.

Shoaib A and Arabi MIE (2006). Genetic diversity among Syrian cultivated and landraces wheat revealed by AFLP markers. Genet. Resour. Crop Evol. 53: 901-906.

Sofallan, O.; Chaparzadeh, N. and Dolati, M. (2009): Genetic Diversity in Spring Wheat Landraces from Northwest of Iran Assessed by ISSR Markers. Not. Bot. Hort. Agrobot. Cluj. 37 (2):252-256.

van Slageren MW (1994). Wild Wheats: a monograph of Aegilops L. and Amblyopyrum (Jaub. \& Spach) Eig (Poaceae). Wageningen Agricultural University Papers 94-97, Wageningen, the Netherlands.

Vos P, Hogers R, Bleeker M, Reijans M, Van De Lee T, Hornes M, Fritjers A, Pot J, Peleman J, Kuiper M, Zabeau M (1995). AFLP: a new technique for DNA fingerprint. Nucleic Acid Res. 23: 4407-4414. 


\title{
تقدير التنوع الوراثي بين بعض أصناف القمح السداسى و الرباعى و الراى و التريتيكال باستخدام تكنيك تكرارات

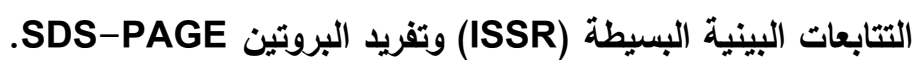

\author{
رحاب مصطفى الشرقاوى، إبراهيم إبراهيم الثواف، مخلوف بخيت، هدى الجارحى و تامر محمد شحاتة \\ قسم الوراثة و الهندسة الوراثية، كلية الزراعة ، جامعة بنها
}

تم تقدير التتوع الوراثي بين بعض التراكيب الوراثية للقمح و الاجناس القريبة (الراى و التريتيكال) باسـتخدام تكنيك تكرارات التتابعات البينية البسيطة

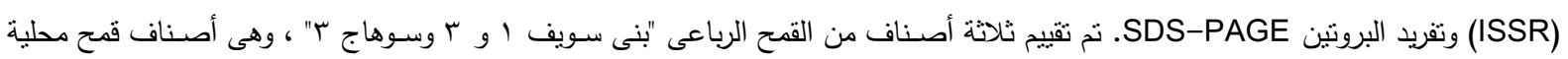

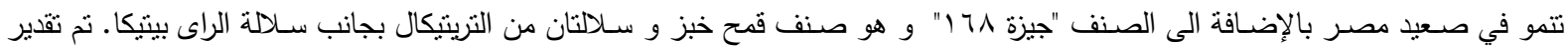

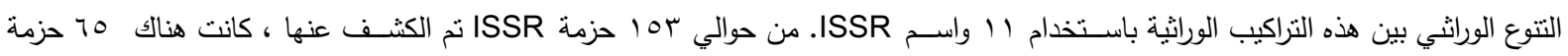

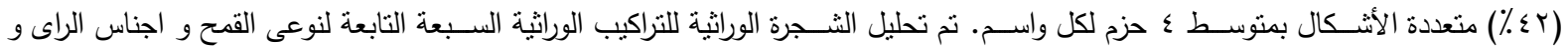

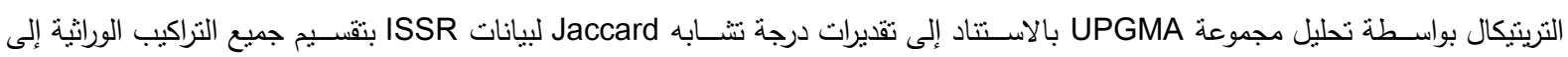

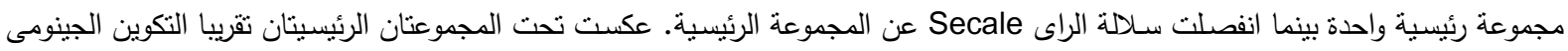

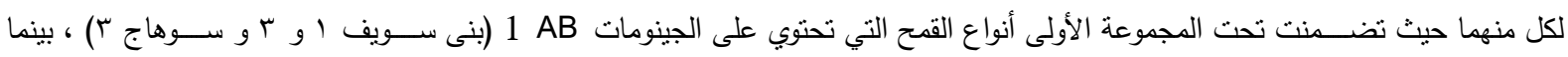

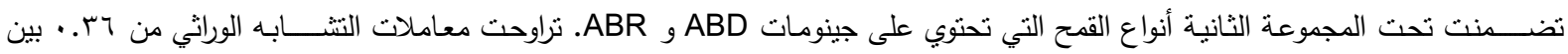
Triticale 1

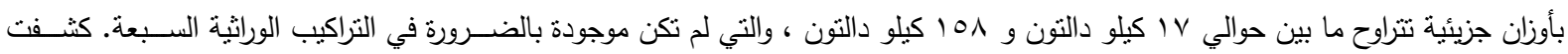

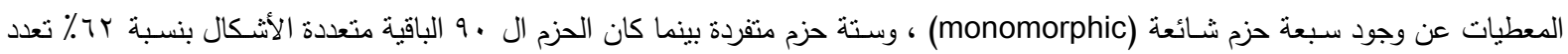

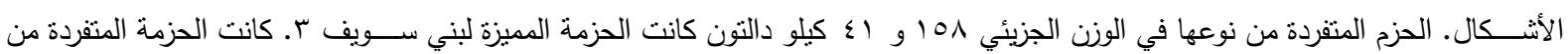

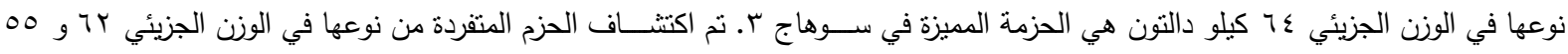

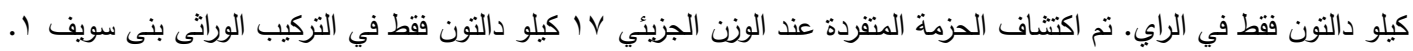

